\title{
KARAKTERISTIK FISIKOKIMIA KALSIUM DARI TULANG NILA (Oreochromis niloticus) DENGAN PERENDAMAN BELIMBING WULUH
}

\author{
Ima Wijayanti*, Laras Rianingsih, Ulfah Amalia \\ Program Studi Teknologi Hasil Perikanan, Fakultas Perikanan dan Ilmu Kelautan, Universitas Diponegoro \\ Jalan. Prof. Soedharto, SH, Semarang 50275 \\ Telepon (224) 7474698, Fexs (224) 7474698 \\ *Korespondensi: imasetianto@gmail.com \\ Diterima: 6 Juli 2017/ Disetujui: 11 Juli 2018
}

Cara sitasi: Wijayanti I, Rianingsih L, Amalia U. 2018. Karakteristik fisikokimia mikrokalsium dari tulang nila (Oreochromis niloticus) dengan perendaman belimbing wuluh. Jurnal Pengolahan Hasil Perikanan Indonesia. 21(2): 336-344.

\begin{abstract}
Abstrak
Kandungan asam yang tinggi pada belimbing wuluh diduga dapat menjadi alternatif pengganti asam pada proses ekstraksi kalsium. Penelitian ini bertujuan menentukan pengaruh konsentrasi dan lama perendaman terhadap karakteristik kimia dan fisika kalsium dari tulang ikan nila. Penelitian menggunakan rancangan faktorial dengan faktor konsentrasi blimbing wuluh (40\%, 60\% dan 80\%) dan lama perendaman (24 jam dan 48 jam). Parameter uji yang digunakan terdiri dari analisis kadar kalsium, ukuran partikel, kadar air, protein, lemak, abu dan SEM. Interaksi konsentrasi dan lama perendaman berpengaruh nyata terhadap kadar kalsium, ukuran partikel, rendemen, kadar abu namun tidak berpengaruh nyata pada kadar air, protein dan lemak. Perlakuan terbaik dengan kadar kalsium yang memenuhi standar dengan ukuran partikel yang relatif kecil adalah konsentrasi $40 \%$ dengan lama perendaman 48 jam.
\end{abstract}

Kata kunci: kalsium, SEM, tulang ikan nila, ukuran partikel

\section{Physicochemical Characteristics Calsium from Tilapia Bone (Oreochromis niloticus) Soaking in Averrhoa bilimbi}

\begin{abstract}
High acid content in bilimbi fruits (Averrhoa bilimbi) can be functioned as an alternative to chemical acid in the calcium extraction process. This study was aimed to determine the effect of concentration and duration of immersion on chemical characteristics and calcium physics of tilapia bone. Research design in this study was faktorial $3 \times 2$ with concentration faktor $(40 \%, 60 \%$ and $80 \%)$ and imersing time (24 and 48 hours) bilimbi. The test parameters used are calcium content determination, particle size, moisture content, protein, fat, ash and SEM. Interaction of concentration and immersing duration significantly affected the calcium content, particle size, yield, ash content but have no significant effect on moisture content, protein and fat. The best treatment with high content calcium that fullfill the standard with relatively small particle size was a concentration of $40 \%$ with 48 hours of immersion.
\end{abstract}

Keywords : calcium, particle size, SEM, tilapia bone, 


\section{PENDAHULUAN}

Ikan nila merupakan salah satu komoditi hasil budidaya yang produksinya mengalami peningkatan dari tahun ke tahun. Jumlah produksi ikan nila pada tahun 2011 mencapai 22.534 ton dan pada tahun 2012 meningkat menjadi 27.386 ton (KKP 2014). Ikan nila banyak digemari di dalam dan luar negeri, konsumsi nila di dunia mencapai $30-40 \%$ per tahun. Perusahaan yang menggarap pasar ekspor salah satunya adalah PT. Aquafarm Nusantara. Aquafarm terus berupaya meningkatkan produksi, untuk menghasilkan fillet siap ekspor, setiap hari Aquafarm mengolah 73 ton nila yang masih hidup dan segar (Dadang et al. 2007).

Permintaan daging filet nila yang tinggi menyebabkan limbah tulang yang dihasilkan juga tinggi. Limbah tulang ikan berpotensi dimanfaatkan menjadi sumber kalsium. Menurut Stanek et al. (2013), tulang ikan memiliki kandungan kalsium $(5,63 \mathrm{~g} / \mathrm{kg})$ dan fosfor $(2,38 \mathrm{~g} / \mathrm{kg})$. Tulang ikan merupakan salah satu bentuk limbah dari industri pengolahan ikan yang memiliki kandungan kalsium cukup banyak di antara bagian tubuh ikan, karena unsur utama dari tulang ikan adalah kalsium, fosfor dan karbonat (Trilaksani et al. 2006).

Ekstraksi kalsium sudah banyak dilakukan menggunakan asam maupun basa. Penggunaan asam dan basa pada ekstraksi kalsium bertujuan untuk memisahkan protein dari matriks tulang (Lekahena et al. 2014). Protein akan terhidrolisis apabila dicampur dengan asam, alkali kuat atau enzim proteolitik melalui proses pemecahan protein secara bertahap menjadi molekul-molekul peptida dan asam-asam amino. Ekstraksi tulang ikan menjadi kalsium berukuran nano sudah dilakukan, antara lain Trilaksani et al. (2006) yang menggunakan proses hirolisis protein untuk mengekstrak kalsium dari ikan tuna, Lekahena et al. (2014) ekstraksi nanokalsium menggunakan asam dan basa.

Penggunaan asam dan basa pada proses ekstraksi dikhawatirkan menimbulkan residu kimia yang dapat membahayakan. Penggunaan bahan alami untuk mengekstrak nanokalsium masih belum dilakukan. Belimbing wuluh (Averrhoa bilimbi L) merupakan salah satu sumber asam alami yang dapat digunakan.
Belimbing wuluh (Averrhoa bilimbi L) adalah buah yang banyak tersebar di Indonesia sebagai tanaman pekarangan rumah yang belum dibudidayakan dan dikembangkan pemanfaatannya. Buah belimbing wuluh memiliki kandungan asam yang tinggi dan kadarair buah yang tinggi menyebabkan buah jarang dikonsumsi layaknya buah segar. Pemanfaatan dan pengembangan buah belimbing wuluh di Indonesia masih belum optimal, karena nilai jual buah yang masih rendah dan tidak diimbangi dengan potensi yang dimiliki buah belimbing wuluh (Ferawati 2005). Kajian mengenai belimbing wuluh sebagai bahan yang mengandung bioaktif sudah banyak dilakukan, di antaranya belimbing wuluh sebagai antioksidan (Hasanuzzaman et al. 2013), antibakteri (Abraham 2016), antikanker (Nair et al. 2016), namun kajian belimbing wuluh dalam teknologi pengolahan pangan masih terbatas. Kandungan asam pada belimbing wuluh diduga dapat digunakan dalam proses ekstraksi tepung kalsium.

Kandungan asam yang tinggi pada belimbing wuluh diduga dapat menjadi alternatif pengganti asam pada proses ekstraksi kalsium, dengan menghidrolisis protein pada tulang sehingga dapat terlepas dari matriks tulang. Aminonatalina et al. (2016) melaporkan bahwa konsentrasi 60\% belimbing wuluh dapat mereduksi formalin dari daging ikan. Penurunan kadar formalin dari daging ikan karena terlepasnya formalin yang terikat pada protein akibat adanya belimbing wuluh. Penelitian ini bertujuan menentukan pengaruh konsentrasi dan lama perendaman terhadap karakteristik kimia dan fisika kalsium dari tulang ikan nila.

\section{BAHAN DAN METODE Bahan dan Alat}

Bahan yang digunakan dalam penelitian ini adalah tulang ikan nila dari perusahaan pembekuan filet ikan nila PT. Aquafarm Nusantara, bahan kimia yang dugunakan untuk analisis antara lain: $\mathrm{H}_{2} \mathrm{SO}_{4}, \mathrm{NaOH}$, $\mathrm{HCl}, \mathrm{H}_{3} \mathrm{BO}_{3}$, Heksana (Merck, Germany). Belimbing Wuluh yang digunakan dengan kondisi buah yang masih mentah, diperoleh di pasar tradisional di Semarang. 
Alat-alat yang digunakan dalam penelitian yaitu hammer miil, waterbath (Memmert Germany); peralatan gelas (Iwaky pyrex), oven (Memmert Germany), kjeltec system (Kjeltec ${ }^{\mathrm{TM}} 8000$ FOSS), tanur (Memmert Germany), soxlet apparatus (Sigma Aldrich), desikator, $\mathrm{pH}$ meter digital, Spektrofotometer Serapan Atom (SSA) (Thermo Fisher Scientific iCE 3000 Series AA spectrometers) dan Particle Analyzer (Beckman Coulter Delsa Nano Particle analyzer), SEM (JEL, JSM-5800 LV, Tokyo, Japan).

\section{Metode Penelitian \\ Pembuatan ekstrak belimbing wuluh}

Pembuatan ekstrak belimbing wuluh mengacu pada Wikanta et al. (2011) dengan modifikasi penyaringan. Belimbing wuluh segar dibersihkan, kemudian dihaluskan dengan alat blender selanjutnya disaring menggunakan penyaring santan ukuran 100 mesh. Hasil penyaringan ditampung dalam wadah sebagai stok untuk pembuatan konsentrasi ekstrak belimbing wuluh sesuai perlakuan dalam penelitian ini (40; 60 dan $80 \%)$.

\section{Pembuatan tepung tulang mikrokalsium}

Prosedur pembuatan kalsium dari tulang nila mengacu pada Lekahena et al. (2014) dengan modifikasi pada perendaman belimbing wuluh. Ekstrak belimbing wuluh (40; 60 dan 80\%) ditambahkan pada bubuk tulang kasar dan direndam selama 24 dan 48 jam.

\section{Analisis kalsium}

Analisis kalsium yang digunakan adalah SSA (spektrofotometer serapan atom) mengacu pada Rohman dan Sumantri (2007). Prinsip penetapan kadar mineral dengan SSA adalah setelah bahan organik dalam sampel dimusnahkan dengan pengabuan kering atau pengabuan basah, sisa abu dilarutkan dalam asam encer. Logam yang diatomisasi dalam nyala akan menyerap energi tertentu yang diemisikan oleh lampu katoda. Jumlah energi terserap oleh logam sebanding dengan konsentrasi mineral dalam sampel. Logam Ca berada pada panjang gelombang $422,7 \mathrm{~nm}$.

\section{Analisis Particle Size Analyzer}

Analisis Particle Size Analyzer (PSA) merupakan analisis yang digunakan untuk menentukan ukuran partikel dari suatu sampel, mengacu pada metode Yang et al. (2014). Sampel larutan kalsium sebanyak \pm 1 $\mathrm{mL}$ dimasukkan ke dalam alat PSA untuk diuji ukuran nanopartikel. Prinsip kerja dari alat PSA ini adalah menggunakan metode difraksi sinar laser yang ditembakkan pada sampel cair yang diuji, partikel di dalam larutan sampel tersebut mengalami pergerakan yang disebut gerak brown. Sumber cahaya (laser) yang digunakan pada alat PSA dalam penelitian ini menggunanakan prinsip Dynamic Light Scattering (DLS). Pengukuran dengan alat dilakukan pada suhu ruang. Suhu ini memengaruhi dari gerakan partikel larutan (gerak brown) selama pengukuran oleh alat, semakin tinggi suhu maka gerak partikel semakin aktif, hal ini berpengaruh terhadap keakuratan hasil pengukuran. Interpretasi hasil uji dari PSA ini dapat ditunjukkan berdasarkan volume dan intensitas sampel.

\section{Analisis kimia tulang ikan nila}

Analisis proksimat tulang ikan nila terdiri dari kadar air, protein, lemak dan abu, dianalisis menggunakan metode AOAC (2005).

\section{Rendemen}

Rendemen adalah rasio antara berat bagian yang dapat dimanfaatkan terhadap berat utuh analisis rendemen mengacu pada metode (Hadiwiyoto 1993). Rendemen umumnya digunakan untuk memperkirakan jumlah bagian yang bisa dimanfaatkan sebagai bahan pangan. Rendemen nanokalsium tulang ikan nila dihitung dengan rumus sebagai berikut :

Rendemen HPI (\%)= $\frac{\text { Berat tulang ikan nila }(\mathrm{g})}{\text { Berat nanokalsium }(\mathrm{g})} \times 100 \%$

\section{Scanning Electron Microscopy (SEM)}

Mikrostruktur nanokalsium ditentukan menggunakan SEM mengacu pada metode Balange dan Benjakul (2009). Sampel dengan ketebalan 2-3 mm dicampur dengan 
glutaraldehida $2,5 \%(\mathrm{v} / \mathrm{v})$ dalam buffer fosfat $0,2 \mathrm{M}$ (pH 7,2). Sampel kemudian dibilas selama 1 jam dengan akuades sebelum didehidrasi dalam etanol dengan seri konsentrasi 50; 70; 80; 90 dan 100\% (v/v), selanjutnya sampel kering ditempel pada potongan perunggu dan dilapisi dengan emas (Sputter coater SPI-Module, PA, USA). Spesimen tersebut kemudian diamati dengan scanning electron microscope pada percepatan tegangan $10 \mathrm{kV}$.

\section{Analisis Data}

Penelitian dilakukan secara eksperimen di Laboratorium. Rancangan percobaan pada penelitian adalah rancangan acak lengkap factorial $3 \times 2$ dengan faktor pertama konsentrasi belimbing wuluh $(40 ; 60$ dan $80 \%)$ dan faktor kedua lama perendaman belimbing wuluh (24 dan 48 jam). Analisis data penelitian menggunakan analisis ragam (ANOVA) untuk menentukan pengaruh konsentrasi dan lama perendaman belimbing wuluh terhadap karakteristik kalsium tulang ikan nila. Uji lanjut BNJ (Tukey) dilakukan apabila perlakuan berpengaruh nyata.

\section{HASIL DAN PEMBAHASAN Kadar Kalsium}

Kadar kalsium tepung tulang ikan nila dengan konsentrasi dan lama perendaman belimbing wuluh disajikan pada Gambar 1. Kadar kalsium belimbing wuluh yang digunakan pada penelitian ini adalah $0,67 \% \pm 0,03 \%$. Hasil analisis ragam menunjukkan terdapat interaksi antara konsentrasi dan lama perendaman belimbing wuluh terhadap kadar kalsium tepung tulang ikan $(\mathrm{P}<0,05)$.

Kadar kalsium tertinggi terdapat pada tepung tulang ikan dengan konsentrasi belimbing wuluh $60 \%$ dengan lama perendaman 48 jam yaitu 20,85\% namun tidak berbeda nyata dengan perlakuan belimbing wuluh $40 \%$ lama perendaman 48 jam (20,66\%). Kadar kalsium dengan perlakuan konsentrasi ekstrak belimbing wuluh $40 \%$, $60 \%$ dan $80 \%$ dengan lama perendaman 24 jam tidak berbeda nyata dengan perendaman 48 jam pada konsentrasi $80 \%$ hal tersebut menunjukkan bahwa lama perendaman 48 jam efektif pada konsentrasi 40 dan $60 \%$ namun tidak efektif untuk konsentrasi $80 \%$.

Kadar kalsium pada tepung tulang nila hasil penelitian ini hampir sama dengan hasil penelitian Anggraen et al. (2016) yang menunjukkan kadar kalsium tepung tulang ikan nila 19,27\% dan Lekahena et al. (2014) $20,47 \%$ pada ekstraksi basa dan $21,48 \%$ pada ekstraksi asam. Kadar kalsium tulang nila hasil penelitian ini lebih rendah dibandingkan hasil penelitian Trilaksani et al. (2006) pada tulang ikan tuna yaitu $23,7 \%-39,4 \%$ dengan perlakuan hidrolisis protein. Putranto et al. (2016) melaporkan bahwa pada tulang ikan belida dengan kadar kalsium 23-39\%. Standar

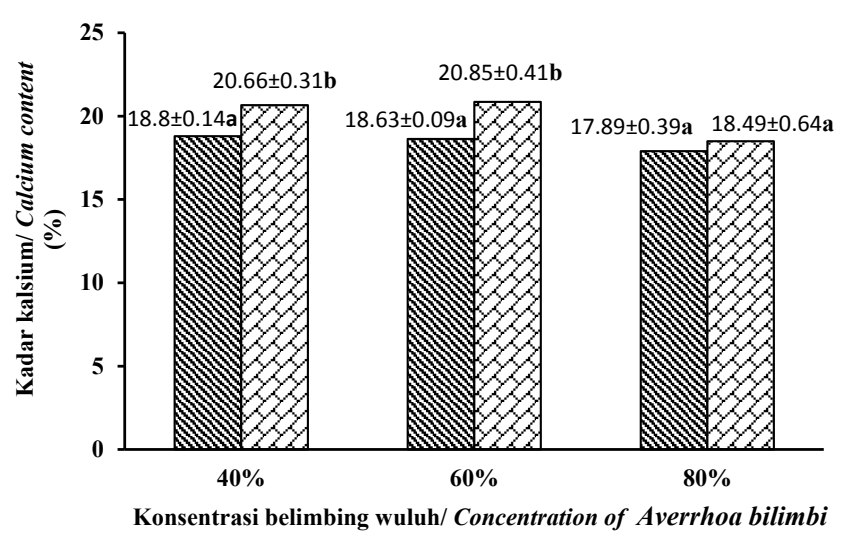

Gambar 1 Kadar kalsium tepung tulang ikan nila dengan konsentrasi dan lama perendaman belimbing wuluh yang berbeda. Lama peren daman: 24 jam (N) ) dan 48 jam (BS ).

(Figure 1 Calcium Content of calcium bone meal from tilapia with different duration and concentration of Averrhoa bilimbi soaking. Soaking

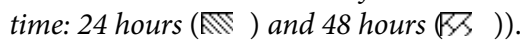


kalsium tepung tulang mutu 1 minimum $30 \%$ dan mutu II minimum 20\% (BSN 1992), sehingga pada peneltian ini 2 perlakuan yang memenuhi standar SNI yaitu tepung tulang pada perendaman belimbing wuluh $40 \%$ dan $60 \%$ dengan lama perendaman 48 jam.

\section{Ukuran partikel kalsium}

Analisis ukuran partikel tepung kalsium menggunakan Partcile Size Analyzer (PSA). Hasil analisis ukuran partikel tepung kalsium dengan konsentrasi dan lama perendaman belimbing wuluh yang disajikan pada Tabel 1 .

Konsentrasi dan lama perendaman memberikan efek yang berbeda pada ukuran partikel. Ukuran partikel terkecil pada perendaman belimbing wuluh dengan konsentrasi $60 \%$ dan lama perendaman 24 jam, sedangkan ukuran partikel terbesar pada tepung kalsium dengan perendaman belimbing wuluh $60 \%$ dengan lama perendaman 48 jam.

Ukuran partikel tepung tulang ikan nila masih cukup besar yaitu 1.158,1-4.455,4 nm. Ukuran tersebut belum bisa dikatakan nano, menurut Mohanraj dan Chen (2006) suatu zat dikatakan nano apabila memiliki ukuran 1-1.000 nanometer. Penggunaan belimbing wuluh sebagai bahan untuk ekstraksi nanokalsium tidak sekuat penggunaan $\mathrm{HCl}$ maupun $\mathrm{NaOH}$, namun penggunaan belimbing wuluh dalam ekstraksi ini mampu mengekstraksi kalsium dengan ukuran mikro yaitu 1,1-4,4 mikro.

\section{Rendemen}

Rendemen tepung tulang ikan nila dengan konsentrasi dan lama perendaman belimbing wuluh berbeda disajikan pada
Gambar 2. Analisis ragam menunjukkan terdapat interaksi nyata antara konsentrasi dan lama perendaman $(\mathrm{P}<0,05)$ terhadap rendemen tepung tulang ikan nila. Kombinasi konsentrasi dan lama perendaman memberikan pengaruh yang berbeda pula terhadap rendemen tepung tulang.

Rendemen tepung tulang pada penelitian ini berkisar 18-36\%. Rendemen tertinggi pada tepung tulang dengan konsentrasi belimbing wuluh $40 \%$ dengan lama perendaman 24 jam namun tidak berbeda nyata dengan rendemen tepung tulang dengan konsentrasi belimbing wuluh $60 \%$ dan $80 \%$ dengan perendaman 24 jam. Rendemen terendah pada tepung tulang dengan konsentrasi $80 \%$ dengan lama perendaman 48 jam.

\section{Kadar Air}

Data kadar air disajikan pada Tabel 2. Hasil analisis statistik menunjukkan tidak terdapat interaksi antara konsentrasi dan lama perendaman belimbing wuluh terhadap kadar air tepung tulang $(\mathrm{P}>0,05)$ dan masing-masing faktor juga tidak memberikan pengaruh yang nyata $(\mathrm{P}>0,05)$.

Kadar air tepung ikan yang dihasilkan cukup rendah yaitu berkisar antara 4,37\%$5,27 \%$. Kadar air pada semua perlakuan tidak berbeda nyata. Kadar air hasil penelitian ini masih memenuhi kriteria tepung tulang berdasarkan SNI 01-31581992 yang mensyaratka kadar air tepung tulang maksimum 8\% (BSN 1992). Kadar air hasil tepung kalsium dengan perendaman belimbing wuluh pada penelitian ini tidak jauh berbeda dengan hasil penelitian Lekahena et al. (2014) yang menunjukkan tepung tulang ikan nila dengan perlakuan

Tabel 1 Ukuran partikel (nm) tepung kalsium dari tulang ikan nila dengan konsentrasi dan lama perendaman belimbing wuluh yang berbeda

(Table 1 Particle size of calcium bone meal from tilapia with with different duration and concentration of Averrhoa bilimbi soaking)

\begin{tabular}{ccc}
\hline \multirow{2}{*}{$\begin{array}{c}\text { Konsentrasi belimbing wuluh } \\
\text { concentration of Averrhoa bilimbi }\end{array}$} & \multicolumn{2}{c}{$\begin{array}{c}\text { Lama perendaman (jam) } \\
\text { Soaking time (hours) }\end{array}$} \\
\cline { 2 - 3 } $40 \%$ & 24 & 48 \\
$60 \%$ & $3119.3 \mathrm{~nm}$ & $1158.1 \mathrm{~nm}$ \\
$80 \%$ & $1887.0 \mathrm{~nm}$ & $4455.4 \mathrm{~nm}$ \\
\hline
\end{tabular}




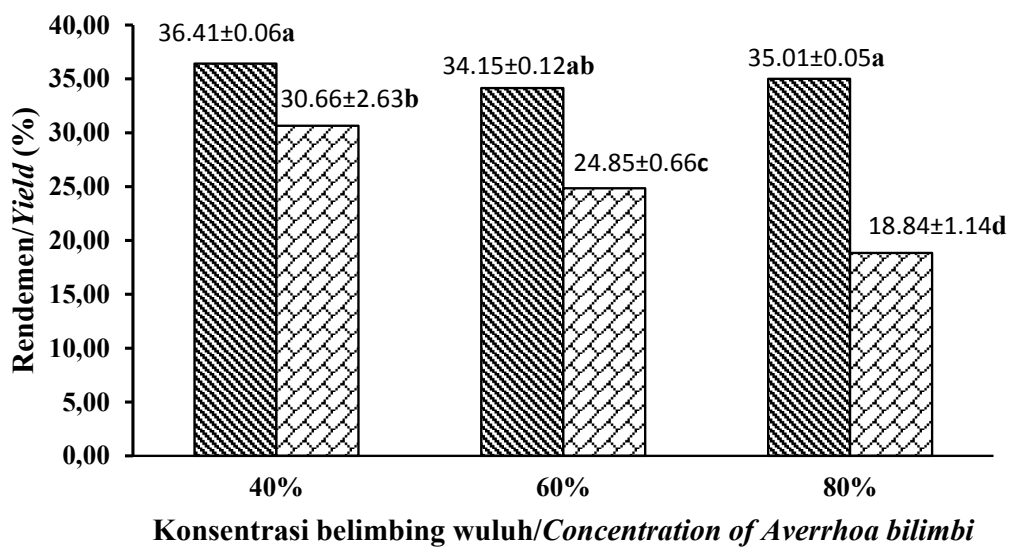

Gambar 2 Rendemen tepung tulang ikan nila dengan konsentrasi dan lama perendaman belimbing wuluh yang berbeda. Lama perendaman: 24 jam (W) dan 48 jam ( $Q$ ).

Picture 2 Yild of calcium bone meal from tilapia with different duration and concentration of Averrhoa bilimbi soaking. Soaking time: 24 hours ( $)$ and 48 hours ( $Q$ )

$\mathrm{HCl}$ mempunyai kadar air 4,41\% dan dengan $\mathrm{NaOH} 5,91 \%$. Kadar air hasil penelitian ini lebih rendah dari hasil penelitian Trilaksani et al. (2006) yang melaporkan kadar air tepung tulang ikan dengan metode hidrolisis 5,6\% namun lebih tinggi dari penelitian Putranto et al. (2015) pada tepung tulang belida dengan kadar air berkisar 3,12-3,99\%.

\section{Kadar Protein}

Kadar protein tepung tulang ikan nila dengan konsentrasi dan lama perendaman yang berbeda disajikan pada Tabel 2. Hasil analisis ragam menunjukkan tidak terdapat interaksi yang nyata antara konsentrasi dan lama perendaman terhadap kadar protein tepung kalsium ikan nila $(\mathrm{P}>0,05)$, faktor lama perendaman tidak berbeda nyata $(P>0,05)$, namun faktor konsentrasi memberikan pengaruh nyata terhadap kadar protein $(\mathrm{P}<0,05)$. Faktor konsentrasi belimbing wuluh $40 \%$ mempunyai kadar protein tertinggi (26,83-27,05\%) dibandingkan pada perlakuan $60 \%$ dan $80 \%$.

Kadar protein hasil penelitian ini jauh lebih tinggi dari hasil beberapa penelitian dengan metode yang sedikit berbeda antara lain Trilaksani et al. (2006) yaitu 0,48\%1,29\%; Anggraen et al. (2016) $0,21 \%$ dan Putranto et al. (2015) 0,26\%-14,25\%. Kadar protein hasil penelitian ini masih lebih rendah dibandingkan penelitian Apriliani (2010) yaitu $33,5 \%$.
Kadar protein tepung tulang ikan hasil ekstraksi dengan belimbing wuluh tergolong tinggi dibandingkan dengan ekstraksi dengan asam $(\mathrm{HCl})$ dan basa $(\mathrm{NaOH})$. Trilaksani et al. (2006) menyatakan kandungan protein yang masih tinggi juga dapat menguntungkan penyerapan kalsium di dalam mukosa usus karena transportasi kalsium melalui sel usus dapat terjadi melalui difusi yang menggunakan jasa protein pengikat kalsium yang mengantarkan sitoplasma eritrosit ke membrane basal. Harland dan Oberleas (2001) melaporkan bahwa asam amino lisin dan arginine mampu mendorong penyerapan kalsium di dalam usus.

\section{Kadar Lemak}

Kadar lemak tepung tulang ikan disajikan pada Tabel 2. Analisis ragam menunjukkan tidak terdapat interaksi nyata antara konsentrasi dan lama perendaman belimbing wuluh terhadap kadar lemak tepung tulang ikan $(P>0,05)$, namun masing-masing faktor berpengaruh nyata $(\mathrm{P}<0,05)$.

Konsentrasi ekstrak belimbing wuluh memberikan pengaruh nyata terhadap kadar lemak tepung tulang $(\mathrm{P}<0,05)$. Tepung tulang dengan perendaman belimbing wuluh $80 \%$ mempunyai kadar lemak terendah, sedangkan konsentrasi $40 \%$ dan $60 \%$ tidak berbeda nyata. Lama perendaman berpengaruh nyata terhadap kadar lemak tepung tulang ikan nila $(\mathrm{P}<0,05)$, lama perendaman 48 jam mempunyai kadar lemak yang lebih rendah 
(5,38-7,16\%) dibandingkan perlakuan 24 jam $(7,48-9,54 \%)$. Konsentrasi semakin tinggi (80\%) dan perendaman yang lebih lama (48 jam) mempunyai kadar lemak yang lebih rendah. Rendahnya kadar lemak tepung tulang berbanding terbalik dengan konsentrasi dan lama perendaman.

Kadar lemak tepung tulang hasil penelitian ini tergolong tinggi. Lemak pada tepung tulang yang tinggi dibatasi agar dapat mengurangi resiko ketengikan, sehingga tepung tulang juga lebih awet. BSN (1992) menetapkan standar kadar lemak tepung tulang mutu 1 adalah maksimum 3\% dan mutu II maksimum6\%. Kadar lemak yang memenuhi standar adalah perlakuan konsentrasi 80\% dengan lama perendaman 48 jam (5,38\%), sedangkan perlakuan $40 \%$ dan $60 \%$ belimbing wuluh dengan perendaman 48 jam hampir memenuhi syarat maksimal kadar lemak yang disaratkan oleh BSN. Kadar lemak penelitian ini hampir sama dengan penelitian Hemung (2013) dengan kadar lemak tepung tulang ikan nila 5,82\%.

\section{Kadar Abu}

Kadar abu tepung tulang ikan nila dengan perendaman belimbing wuluh disajikan pada Tabel 2. Hasil analisis ragam menunjukkan terdapat interaksi nyata antara konsentrasi dan lama perendaman $(\mathrm{P}<0,05)$ terhadap kadar abu tepung tulang ikan nila. Kadar abu tertinggi tepung tulang ikan nila diperoleh pada perlakuan konsentrasi 40\% dan lama perendaman 48 jam $(58,15 \%)$ sedangkan terendah pada perlakuan $60 \%$ lama perendaman 24 jam (51,78\%). Kadar abu pada tepung tulang yang tinggi menunjukkan bahan baku tulang ikan yang digunakan mengandung mineral yang lebih dari 50\% termasuk kalsium. Kadar abu penelitian ini hampir sama dengan hasil penelitian Talib et al. (2014) pada tepung tulang ikan tuna yang direbus dengan media air mempunyai kadar abu $56,65 \%$ dan direbus dengan asam asetat $58,21 \%$. Kadar abu penelitian ini lebih rendah dari penelitian Hemung (2013) dan Anggraen (2016) pada tepung tulang nila masing-masing $75,83 \%$ dan $78,82 \%$.

\section{Scanning Electron Microscopi}

Analisis morfologi tepung tulang ikan dengan menggunakan SEM disajikan pada Gambar 3. Gambaran morfologi tepung tulang ikan sejalan dengan hasil ukuran partikel tepung tulang ikan menggunakan PSA. Gambar 3 menunjukkan konsentrasi dan lama perendaman belimbing wuluh memberikan gambaran morfologi yang berbeda pula pada tepung tulang ikan nila.

Gambar 3 menunjukkan bahwa pada perlakuan konsentrasi 60\%, 24 jam (b); konsentrasi 80\%, 24 jam (c) dan konsentrasi $40 \%, 48$ jam (d) mempunyai struktur morfologi yang cenderung lebih halus dibandingkan perakuan a, e dan $\mathrm{f}$ dengan

Tabel 2 Komposisi kimia tepung kalsium dari tulang ikan nila dengan konsentrasi dan lama perendaman belimbing wuluh yang berbeda.

Table 2 Chemical composition of calcium bone meal from tilapia with different duration and concentration of Averrhoa bilimbi soaking

Lama perendaman (jam)/ Soaking time (hours)

$24 \quad 48$

Parameter/ Parameter Konsentrasi Belimbing Wuluh/ Concentration of Averrhoa bilimbi

\begin{tabular}{lcccccc}
\cline { 2 - 7 } & \multicolumn{1}{c}{$40 \%$} & $60 \%$ & $80 \%$ & $40 \%$ & $60 \%$ & $80 \%$ \\
\hline Kadar air/Moisture content & $4.72 \pm 1.33^{\mathrm{a}}$ & $5.14 \pm 11.63^{\mathrm{a}}$ & $4.37 \pm 0.42^{\mathrm{a}}$ & $4.93 \pm 10.78^{\mathrm{a}}$ & $5.27 \pm 10.77^{\mathrm{a}}$ & $4.57 \pm 10.23^{\mathrm{a}}$ \\
Kadar protein/Protein content & $26.83 \pm 0.23^{\mathrm{a}}$ & $25.51 \pm 0.19^{\mathrm{b}}$ & $26.19 \pm 0.40^{\mathrm{b}}$ & $27.05 \pm 0.75^{\mathrm{a}}$ & $25.36 \pm 0.08^{\mathrm{b}}$ & $25.55 \pm 0.02^{\mathrm{b}}$ \\
Kadar lemak/Lipid content & $8.99 \pm 0.34^{\mathrm{ac}}$ & $9.54 \pm 0.22^{\mathrm{ac}}$ & $7.48 \pm 0.37^{\mathrm{bc}}$ & $6.97 \pm 0.30^{\mathrm{ad}}$ & $7.16 \pm 0.45^{\mathrm{ad}}$ & $5.38 \pm 0.33^{\mathrm{bd}}$ \\
Kadar abu/Ash content & $53.89 \pm 0.4^{2 \mathrm{c}}$ & $51.78 \pm 0.06^{\mathrm{d}}$ & $56.32 \pm 0.11^{\mathrm{b}}$ & $58.15 \pm 13^{\mathrm{a}}$ & $52.94 \pm 0.12^{\mathrm{c}}$ & $56.36 \pm 0.00^{\mathrm{b}}$ \\
\hline
\end{tabular}




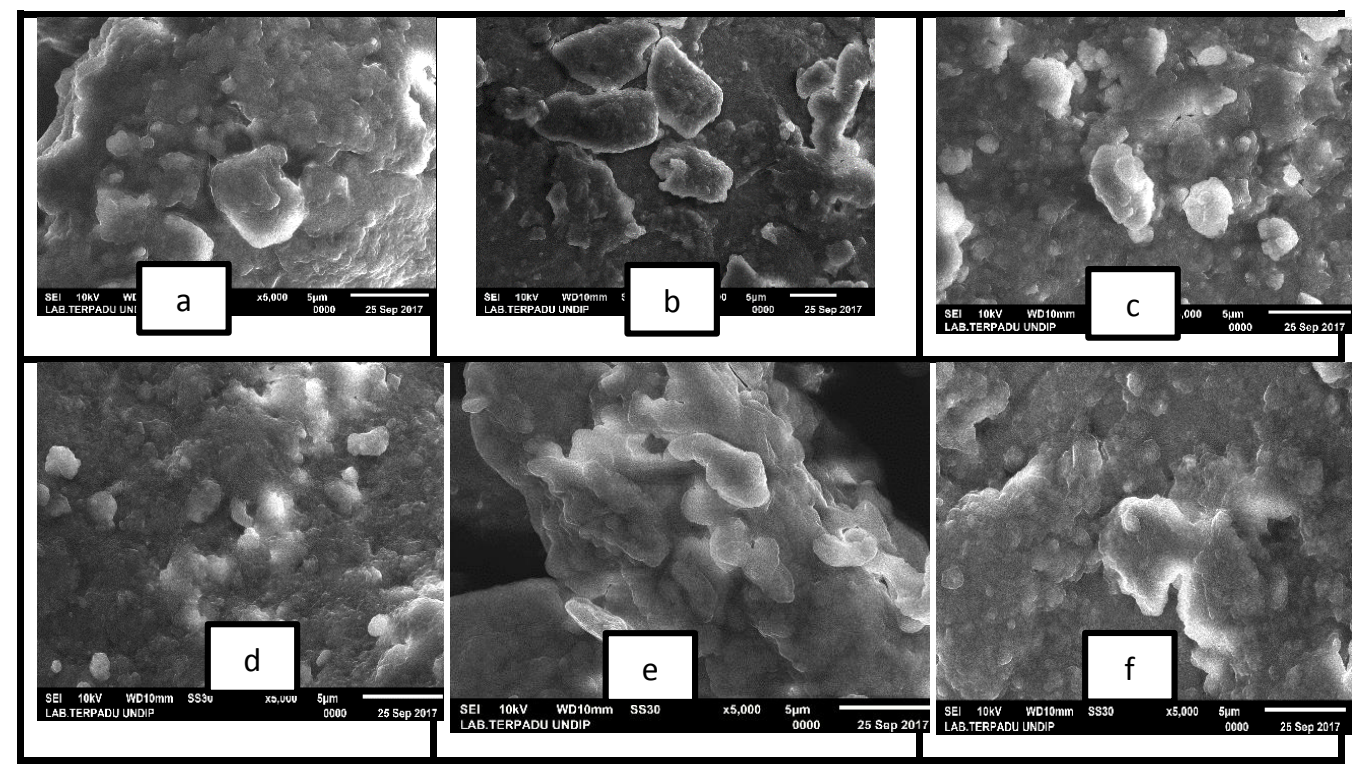

Gambar 3 Scanning Electron Microscopy (SEM) dengan perbesaran 5000x pada tepung tulang ikan nila dengan konsentrasi dan lama perendaman belimbing wuluh yang berbeda. (a) 40\%, 24 jam; (b) 60\%, 24 jam; (c) 80\%, 24 jam; (d) 40\%, 48 jam; (e) 60\% 48 jam; (f) $80 \%, 48$ jam.

(Figure 3 Scanning Electron Microscopy (SEM) with 5000x magnification of calcium bone meal from tilapia with different duration and concentration of Averrhoa bilimbi soaking (a) 40\%, $24 \mathrm{~h}$; (b) 60\%, 24h; (c) 80\%, 24h; (d) 40\%, $48 \mathrm{~h}$; (e) 60\% $48 \mathrm{~h}$; (f) $80 \%$, 48h.)

permukaan yanglebih kasar. Perlakuan dengan konsentrasi $60 \%$ dan lama perendaman 48 jam (e) menunjukkan morfologi yang paling kasar dengan bentuk bongkahan yang besar menunjukkan ukuran partikel yang paling besar. Gambaran morfologi penelitian ini hampir sama dengan penelitian Lekahena et al. (2014) pada ekstraksi tepung tulang menggunakan $\mathrm{HCl}$ memiliki ukuran kristal yang lebih kecil dibandingkan yang menggunakan basa $(\mathrm{NaOH})$

\section{KESIMPULAN}

Interaksi konsentrasi dan lama perendaman berpengaruh nyata terhadap kadar kalsium, ukuran partikel, rendemen, kadar abu namun tidak berpengaruh nyata terhadap kadar air, protein dan lemak. Perlakuan terbaik dengan kadar kalsium yang memenuhi standar, ukuran partikel yang relatif kecil adalah perlakuan konsentrasi $40 \%$ dengan lama perendaman 48 jam.

\section{DAFTAR PUSTAKA}

[AOAC] Association of Official Analytical Chemist. 2005. Official Methods of Analysis of The Association of Official Analytical Chemist. Arlington, Virginia (USA): AOAC Inc.

Abraham CM. 2016. Antibacterial effects of Averrhoa bilimbi L. fruit extracts. International Research Journal of Bilogical Sciences. 5(8): 72-74.

Anggraen N, Darmanto YS, Riyadi PH. 2016. Pemanfaatan nanokalsium tulang ikan nila (Oreochromis niloticus) pada beras analog dari berbagai macam ubi jalar (Ipomoea batatas L.) Jurnal Aplikasi Teknologi Pangan. 5(4): 114-122

Aminonatalina, Mahreda ES, Ahmadi, Santoso UT. 2016. Pengaruh pemberian ekstrak belimbing wuluh (Averrhoa bilimbi) terhadap berat residu formalin ikan tongkol (Euthynnus affinis) berformalin. Enviro Scienteae. 12(3): 160-167. 
Apriliani IS. 2010. Pemanfaatan tepung tulang ikan patin (Pangasius hypophtalmus) pada pembuatan cone es krim. [Skripsi]. Bogor (ID): Institut Pertanian Bogor.

Balange AK, Benjakul, S. 2009. Enhancement of gel strength of bigeye snapper (Priacanthus tayenus) surimi using oxidised phenolic compounds. Food Chemistry. 113: 61-70.

[BSN] Badan Standardisasi Nasional. 1992. SN I 01-3158. Tepung tulang untuk bahan baku makanan ternak. Jakarta (ID): Badan Standardisasi Nasional.

Dadang WIY. Suhendar T. Mardi E. Purbani, Imam, Ike. 2007. Sudah Saatnya Nila Berjaya. http://www.argina-online.com. Diakses. (16 November 2016).

Ferawati, Y. 2005. Pengaruh konsentrasi $\mathrm{CaCl}$ dan metode pengeringan terhadap sifat fisik, kimia dan organoleptik belimbing wuluh kering. [Skripsi]. Malang(ID): Universitas Muhammadiyah Malang.

Hadiwiyoto S. 1993. Dasar-dasar Teknologi Hasil Perikanan. Yogyakarta(ID): Liberty.

Harland FB, Oberleas D. 2001. Effects of dietary fiber and phytat on the homeostatis and bioavailability of minerals. Di dalam: Spiller dan A Gene, editors. Handbooks of Dietary Fiber in Human Nutrition. 3rd $E d$. USA: Library of Congress.

Hasanuzzaman MD. Ramjan Ali, Hossain M, Kuri S, Islam MS. 2013. Evaluation of total phenolic content, free radical scavenging activity and phytochemical screening of different extracts of Averrhoa bilimbi (fruits). International Current Pharmaceutical Journal. 2(4): 92-96.

Hemung B. 2013. Properties of tilapia bone powder and its calcium bioavailability based on transglutaminase assay. International Journal of Bioscience, Biochemistry and Bioinformatics. 3(4): 306-309.

[KKP] Kementrian Kelautan dan Perikanan. 2014. Data Ekspor Ikan Nila. http://.kkp. go.id. (1 November 2016).

Lekahena VDN. Faridah R. Syarief, Peranginangin R. 2014. Karakterisasi fisikokimia nanokalsium hasil ekstraksi tulang ikan nila menggunakan larutan basa dan asam. Jurnal Teknologi dan Industri Pangan. 25(1): 57-64.
Mohanraj VJ, Chen Y. 2006. Nanoparticles: A Review. Tropical Journal of Pharmaceutical Research. 5(1): 562-573.

Nair MS, Soren K, Singh V, Boro B. 2016. Anticancer activity of fruit and leaf extracts of Averrhoa bilimbi on mcf7 human breast cancer cell lines: a preliminary study. Austin Journal Pharmacol and Therapeutics. 4(2): 1-5.

Putranto HF, Andi Noor Asikin dan Indrati Kusumaningrum. 2015. Karakterisasi tepung tulang ikan belida (Chitala sp.) Sebagai sumber kalsium dengan metode hidrolisis protein. ZIRAA'AH. 40(1): 11-20.

Rohman A, Sumantri. 2007. Analisis Makanan. Yogyakarta (ID): Gajah Mada University Press.

Stanek M, Peter E, Janicky B. 2013. Content of the calcium and phosphorus in the meat of Prussian carp (Carassius auratus gibelio $\mathrm{BLOCH}, 1783$ ) from the Lake Gopło (Poland). Journal of Central European Agriculture. 14(1): 1-10.

Talib A, Suprayitno E, Aulaniam, Hardoko. 2014. Physico-chemical properties of Madidihang (Thunnus albacares Bonnaterre) fish bone flour in Ternate, North Moluccas. International Journal of Biosciences. 4(10): 22-30.

Trilaksani W, Salamah E, Nabil M. 2006. Pemanfaatan limbah tulang ikan tuna (Thunus sp.) sebagai sumber kalsium dengan metode hidrolisis protein. Buletin Teknologi Hasil Perikanan. 4(2): 34-45.

Wikanta W, Yusuf Abdurrajak, Sumarno Sumarno, Moh. Amin. 2011. Pengaruh penambahan belimbing wuluh (Averrhoa bilimbi L.) dan perebusan terhadap kadar residu formalin dan profil protein udang putih (Letapenaeus vannamei) berformalin serta pemanfaatannya sebagai sumber pendidikan gizi dan keamanan pangan pada masyarakat. Prosiding Seminar Nasional Biologi. 8(1): 76-84.

Yang MH.Yuan SS, Huang YF, Lin PC, LuCY, Chung TW, Tyan YC. 2014. A proteomic view to characterize the effect of chitosan nanoparticle to hepatic cells. BioMed Research International. 137(6):1-9. 